\title{
Learning from The Legacy of Post-Disaster Recovery in Indonesia for The Acceleration of Post-Disaster Recovery in Lombok
}

\author{
Suprayoga Hadi ${ }^{1}$ \\ Ministry of National Development Planning/Bappenas - Indonesia
}

\begin{abstract}
As a country known for its very disaster-prone areas, Indonesia has experienced frequent disasters, either large, medium and small-scale ones, which even in the last six months have had at least a fairly large-scale natural disaster, one of which is an earthquake occurred in Lombok in late July to midAugust 2018. Learning from the experiences of post-disasters management that have occurred before, especially after the earthquake and tsunami disaster in Aceh and Nias in 2004, the earthquake in Yogyakarta in 2006, the earthquake in West Sumatra in 2009, and eruption of Mount Merapi in 2010, the post-disaster recovery process needs to be carried-out in an integrated and comprehensive manner, by involving participation of stakeholders at the national and regional levels, not only the central government, local governments and other government partners. In relation to the post-earthquake recovery efforts in Lombok in 2018 which affected seven districts/cities in NTB Province which resulted recovery needs of more than $\mathrm{Rp}$. 11 trillion, despite the issuance of the Presidential Instruction policy framework Number 5 of 2018 on the Acceleration of Post-Disaster Rehabilitation and Reconstruction in NTB Province, which assigns relevant ministries/agencies and Governor and Regents and Mayors whose areas are affected in NTB Province, to be able to accelerate the process of recovering local conditions and disaster-affected communities in the affected NTB region, which for implementation still requires operational policies and strategies in the field. For this reason, some best-practices in managing the recovery process from previous disasters can be used as input in establishing appropriate and applicable policies and strategies in order to accelerate the rehabilitation and reconstruction of post-disaster areas in Lombok further, to realize a recovery to rebuild a better one, safer and more sustainable.
\end{abstract}

Keywords: Disaster Management; Recovery Planning; Build Back Better

\footnotetext{
1 Dr. Ir. Suprayoga Hadi, MSP, Primary Planner, Ministry of National Development Planning/Bappenas; Vice Chairman I of Indonesian Disaster Expert Association ( $|A B|)$; and Chairman of Indonesian Government Planners Association (AP2I). E-mail: yogahadi@gmail.com
} 


\title{
Learning from The Legacy of Post-Disaster Recovery in Indonesia for The Acceleration of Post-Disaster Recovery in Lombok
}

\author{
Suprayoga Hadi
}

\section{Introduction}

The earthquake disaster in NTB Province, especially on Lombok Island, which began at the end of July 2018 and continued until mid-August 2018, was a natural disaster that has a significant impact, both from the number of fatalities and refugees that need to be addressed, as well as physical damages and estimated losses, and its impact on the economy and poverty of affected areas, especially in seven districts/cities in West Nusa Tenggara Province that are directly or indirectly affected by the earthquake.

From the results of the post-disaster damage and loss assessment and calculation (JITUPASNA) conducted by National Disaster Management Agency (BNPB) as of September 25, 2018, it was estimated that the overall value of damage and losses reached more than Rp. 16 trillion, and it was estimated that the value of the need for post-disaster recovery has reached more than Rp. 11 trillion, which is spread in seven districts/cities that were directly affected in the NTB Province, as shown in Table 1 below.

Table 1. Results of Need Assessment of Lombok Earthquake, August 2018

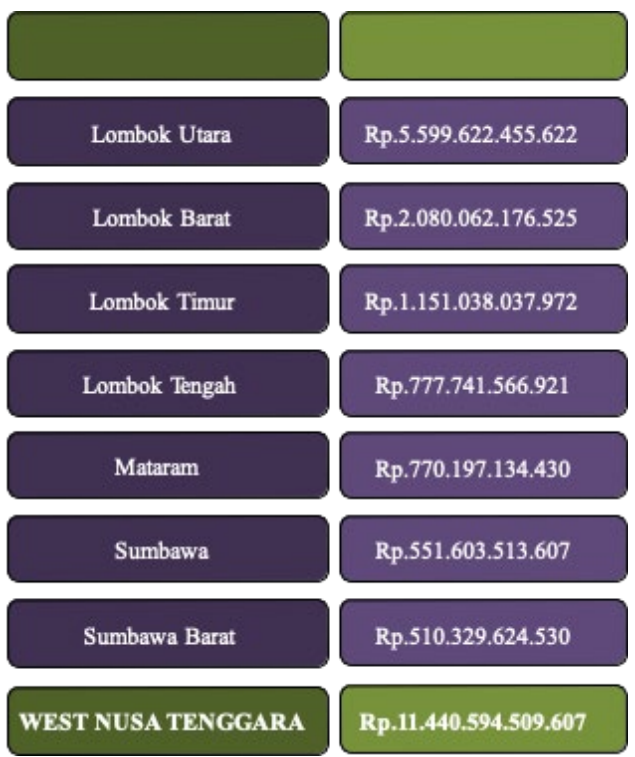

Source: JITUPASNA of Lombok Post-Earthquake, BNPB, 25 September 2018 
From Table 1 above, it appears that the greatest damage and losses are located in West Lombok and North Lombok Districts, where the epicenter of the earthquake occurred several times ranging from 5.6 to 7.0 on the Richter scale, between July 29 and August 9 2018. While in five other districts/cities it is estimated that the value of damage and losses is relatively much lower than that experienced by West Lombok and North Lombok Districts.

While from the results of the interim assessment of the impact of the Lombok earthquake disaster on the national and regional economies, the Ministry of National Development Planning/Bappenas has estimated the national and regional economic impacts, especially in NTB Province, which showed that the impact of the Lombok earthquake was very significant, 66 percent to 4.82 percent, and an increase in inflation from 3.77 percent to 7.25 percent in NTB Province in 2018, which is summarized in Figure 1 below.

Figure 1. Impact of the Lombok Earthquake on the Economy of NTB

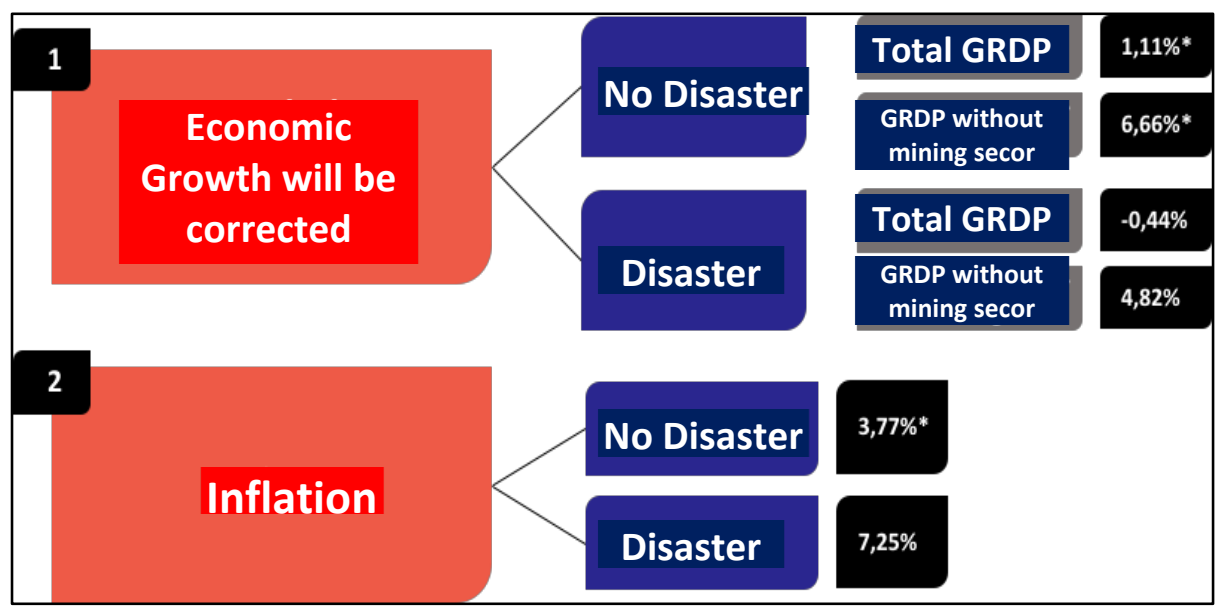

Source: Bappenas, August 2018

In line with the regional economic impact, Bappenas has also conducted an analysis of the impact on output per sector, where there are 2 (two) sectors most significantly affected by the earthquake in Lombok JulyAugust 2018, namely the education sector whose output dropped by 16.8 percent and the settlement sector whose output fell by 14.5 percent, which was complemented by a decline in tourism sector output by 4.9 percent, which is one of the leading sectors in NTB Province, as shown in Figure 2 below. 
Figure 2. Calculation of the Impact of the Lombok Earthquake on Output per Sector (\%)

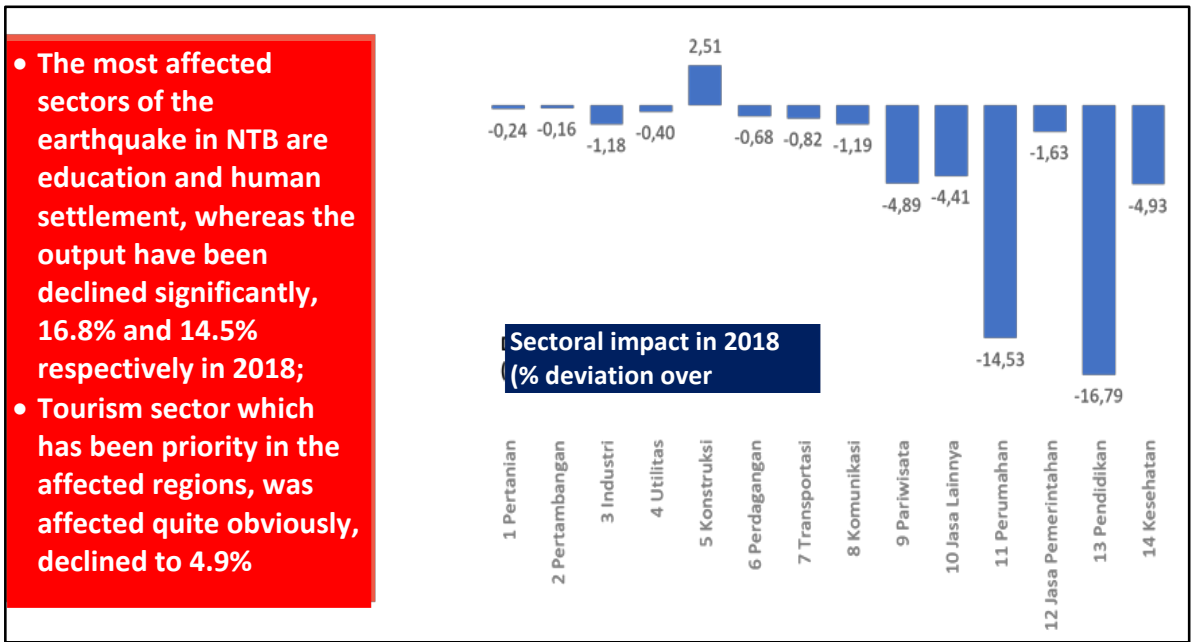

Source: Study and Analysis of the 2018 Lombok Earthquake Disaster Impact, Bappenas, August 2018

As the emergency response phase had been implemented through the NTB Governor's Decree for more than 2 extensions and had been terminated on August 25, 2018, starting from the fourth week of August 2018 a transition period from the end of the emergency response phase to the post-disaster recovery phase through the rehabilitation and reconstruction are scheduled in the short, medium and long term.

In connection with that, taking into account the significant impact of the Lombok July-August 2018 earthquake on the regional economy, as well as sectoral-wise having a significant impact on the education, settlement and tourism sectors, a precise strategy is needed in managing post-earthquake disasters, which can have implications for efforts to accelerate post-disaster recovery that are more efficient and useful, to improve the condition of the community and affected areas in the affected regions in NTB Province.

By paying attention to various experiences in post-disaster recovery practices in other regions, especially by learning from the best practices and lessons learned from previous post-disaster recovery programs, especially in Aceh in 2005-2009, Yogyakarta in 2006-2009, and West Sumatra in 2009-2011, as well as Merapi Eruption in 2010-2012, then in the next section we will discuss several models and strategies for post-disaster recovery management, which can be used as a reference for managing Lombok post-earthquake disaster recovery further. 


\section{Learning from Post-Disaster Recovery Process in Indonesia}

Since 2005 in managing the post-earthquake and tsunami disaster in Aceh-Nias, as well as handling the post-disaster in Yogyakarta-Central Java earthquake in 2006, the Government of Indonesia had tried to establish a structured and well-planned strategy and post-disaster management strategy that began the end of the emergency response phase, from the damage and loss assessment process, or post-disaster assessment and calculation (JITUPASNA), which results the estimation of damage and losses calculated for 5 (five) main sectors, namely housing, public infrastructure, social culture, economy and other cross-sectors.

Furthermore, after an estimate of the value of damage and losses produced by JITUPASNA, then post-disaster need assessment (PDNA) is then carried out, which has taken into account post-disaster recovery needs, both stimulant and assistance for housing rehabilitation and reconstruction, needs of assistance in the recovery of public facilities and infrastructure, government and socio-culture, as well as needs of assistance for economic recovery in the form of subsidies and incentives, which are indirectly aimed at the recovery of the medium and long term non-housing and infrastructure sectors.

Figure 3. Post-Disaster Management Process Based on Action Assessment and Planning

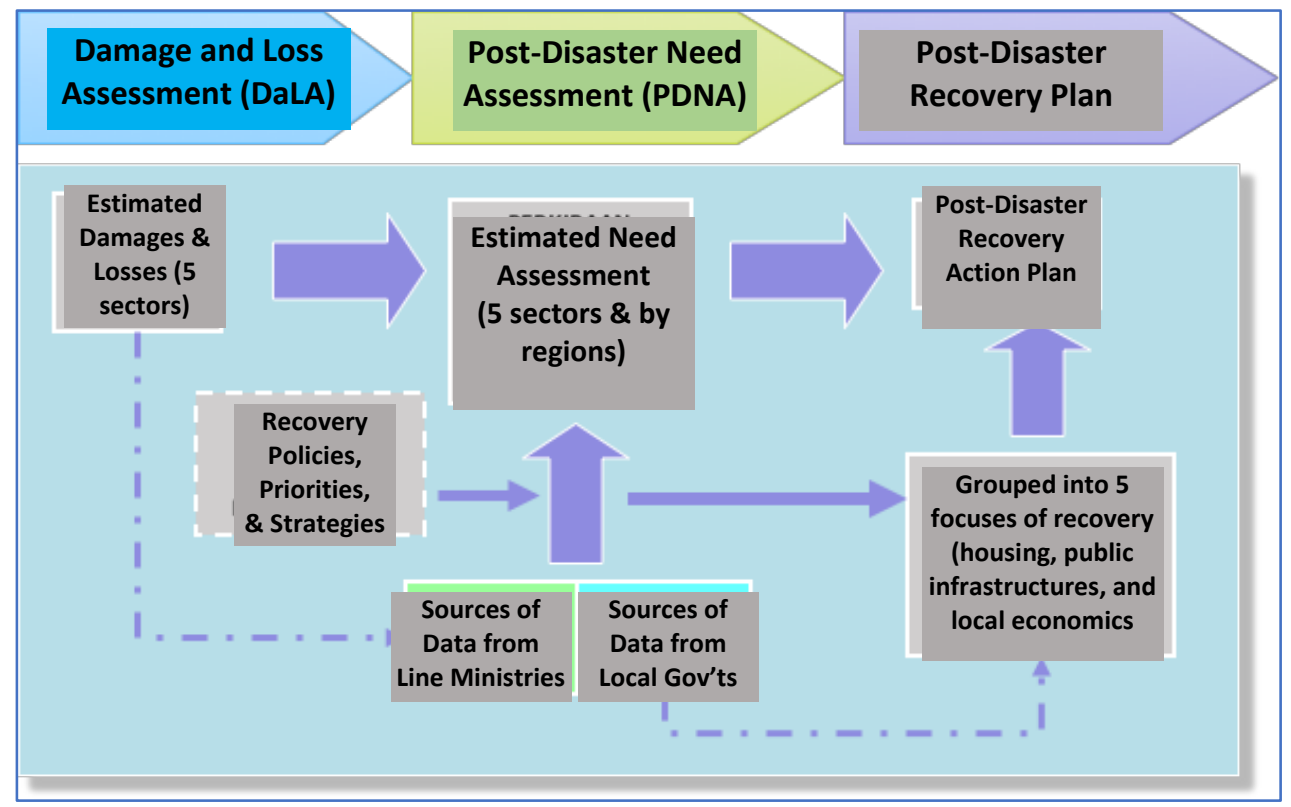

Source: Process for Preparing a Post-Disaster Recovery Action Plan, Bappenas, 2006

Through Figure 3, stages can be learned in the process of post-disaster response, which begins with the assessment of damage and losses, followed by a post-disaster needs assessment, and subsequently the post-disaster recovery 
action plan, which details the rehabilitation and reconstruction process. postdisaster recovery, which is targeted to be resolved, both in the immediate, short, medium to long-term, depending on recovery strategies that have different spectrum and dimensions, from the recovery of short-term housing and public infrastructure, to the recovery of more time-consuming economies in medium to long-term period of recovery.

Therefore, in managing post-disaster recovery that is quite massive as faced after the earthquake and tsunami disaster in Aceh and post-earthquake in Yogyakarta, and post-earthquake in West Sumatra and Merapi Eruption, an integrated, comprehensive, and gradual strategy is needed to complete the process of thoroughly recovery.

Figure 4. Stages of the Post Disaster Recovery Assessment and Planning

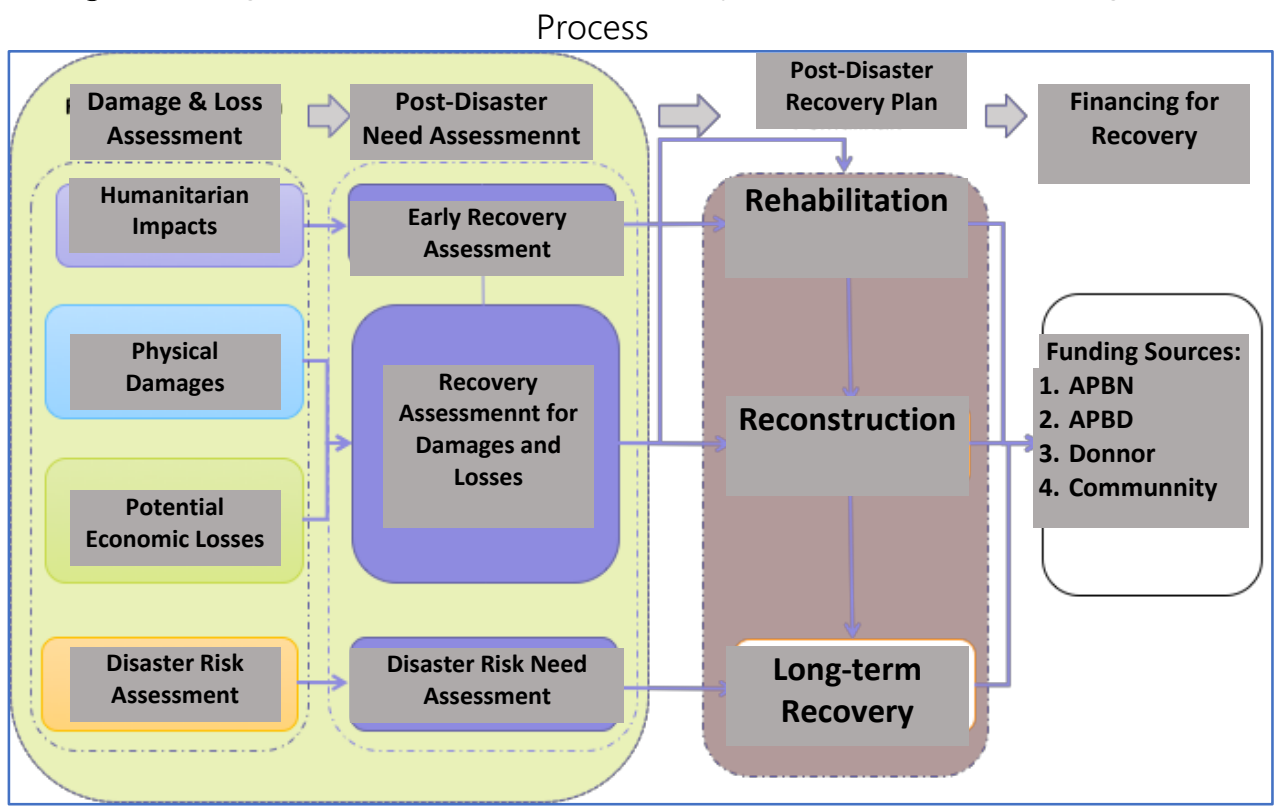

Source: Process of Post-Disaster Recovery Assessment and Planning, Bappenas, 2007

Particularly in the post-disaster need assessment (PDNA) stage, through Figure 4 below, it can be observed that the assessment of needs covers 3 (three) main points, which include identification of the needs for early recovery, then the need for recovery in accordance with the calculation of damage and losses estimated through JITUPASNA, and the need for disaster risk reduction in the recovery process that will be carried out through the rehabilitation and reconstruction of housing and physical infrastructure, as well as socio-cultural community recovery, including the recovery of longer-term economic impacts.

Identification of disaster risk reduction needs in the short-term rehabilitation and reconstruction process, as well as the medium and long-term social and economic recovery, is needed to ensure the long-term recovery 
process is sustainable, as well as to ensure better rebuilding efforts, as wellknown as build back better and safer, for the continuity and sustainability of the post-disaster recovery process as a whole.

Through Figure 4, it can be seen that the recovery action plan that will be compiled as a reference for the subsequent recovery process is not only related to the urgent rehabilitation process, short-term reconstruction, and socioeconomic recovery of communities and regions, but also includes action plans for long-term recovery, which in its implementation requires financial support that is multi-sourcing, both from central, provincial, district/city and village funding sources, also considering the contribution of sources of funding from non-government partners, both from business and the private sector as well as the wider community.

\section{Best Practices of Post-Disaster Recovery Policy and Strategy}

In managing post-disaster recovery process, learning from experiences that have been carried out in the context of recovery after the earthquake and tsunami disaster in Aceh and Nias in 2005, and post-disaster recovery in Yogyakarta-Central Java earthquake in 2006 and after the eruption of Mount Merapi in 2010, can be summarized several key policies which need to be used as a reference in managing the process of Lombok post-earthquake disaster, which consists of several policy directions as follows: First, rebuild better and safer oriented services and ease of public access, and as a life support system and support for regional life and society in disaster affected areas; Second, disaster risk reduction is the main dimension in the implementation of postdisaster rehabilitation and reconstruction for regional and community resilience in disaster preparedness, since the post-disaster recovery aimed at strengthening the regional economy and the community is based on optimizing the use of local resources to achieve better economic growth before the disaster, increasing community income by fostering competitiveness through the development of creative economy based on local wisdom to improve the quality of competitiveness; Third, rebuilding the structure of the regional economy and the community is strengthened by placing regional leading sectors as the driving sector oriented to improving the quality of life, increasing the value of income and quality of life of the people, who have resilience in facing various disaster threats based on competitive advantage and competitiveness; and Fourth, coordinated and integrated budget allocation, by prioritizing the independence of local governments and communities, and the carrying capacity of the Government based on action planning integrated in sustainable development planning by implementing, controlling and evaluating the performance and objectives of the recovery action plan.

Furthermore, learning from the previous experiences of post-disaster that has been done before, several strategies that need to be considered to be a reference in post-disaster management through the process of recovery, 
rehabilitation and reconstruction, including the following management strategies: First, updating disaster risk maps, including vulnerable areas of disaster, which is carried out immediately after the disaster event to obtain the results of potential new risks to be faced, to be used as a basis for preparing the post-disaster rehabilitation and reconstruction plans, so that post-disaster recovery efforts are carried out in anticipation of potential new risks; Second, the development of an information system to facilitate the management of post-disaster rehabilitation and reconstruction funds in an integrated manner from various prospective sources, carried out together with stakeholders involved in financing post-disaster rehabilitation and reconstruction; and Third, the involvement of all stakeholders in post-disaster needs assessment, planning of post-disaster rehabilitation and reconstruction, and managing the implementation, including paying attention to the aspirations and needs of vulnerable groups, so that their needs are met in implementing post-disaster recovery.

Through Figure 5 below, post-disaster recovery management policies and strategies are described in a comprehensive and gradual manner, which provides direction for managing post-emergency response stages, through initial recovery and in-situ rehabilitation and reconstruction processes at affected locations if conditions are still possible, or through relocation or ex-situ recovery to a new location if the condition of the affected location does not allow it to be rebuilt and redeveloped.

Figure 5. Comprehensive Post-Disaster Recovery Process

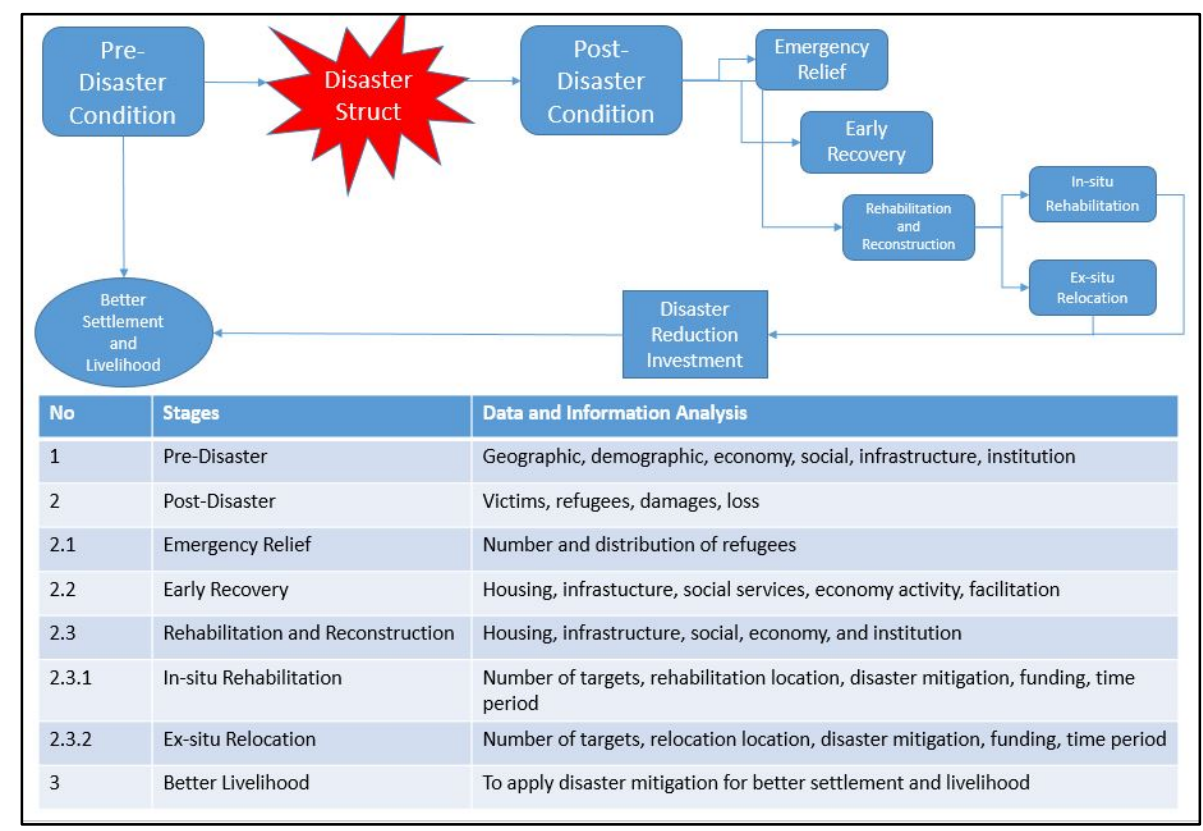

Source: Action Plan for Recovery after Disasters, Bappenas, 2009 and 2010 
From Figure 5 it can be seen that in ensuring the realization of postdisaster recovery that is sustainable, disaster risk reduction investment or intervention is needed in the post-disaster recovery process, as well as realizing recovery to rebuild to create better conditions (build back better and safer), which are targeted the main process of recovery is sustainable in the long- term to realize the conditions of settlements and the economy that are better and safer than the conditions before the occurrence of the disaster.

Furthermore, as a next step in the preparation of a comprehensive plan for rehabilitation and reconstruction and post-disaster recovery, through Figure 5 above, it can also be seen that each stage of post-disaster recovery, which begins with the emergency response phase, is continued with the rehabilitation and reconstruction phase, all of which are intended to realize better housing conditions, within sustainable development framework based on disaster resilience.

\section{Post-Disaster Rehabilitation and Reconstruction Action Plan}

In order to prepare a post-disaster recovery action plan, which consists of an urgent action plan, a short-term reconstruction action plan, as well as an action plan for mid-to long-term social and economic recovery, through the following Table 2 can be observed the recovery target has specific characteristics for each field and for cross-sectors, which aims to be carried out comprehensively and sustainably.

Table 2. Summary of Field-Based Post-Disaster Recovery Needs Assessment

\begin{tabular}{|c|c|}
\hline $\begin{array}{l}\text { Recovery } \\
\text { Sectors }\end{array}$ & Recovery Needs \\
\hline Housing & $\begin{array}{l}\text { To determine relocation location and develop housing and public } \\
\text { facilities }\end{array}$ \\
\hline Infrastructures & To rehabilitate and reconstruct the damage infrastructures \\
\hline $\begin{array}{l}\text { Economic/ } \\
\text { Livelihood }\end{array}$ & $\begin{array}{l}\text { 1. To recover and rebuild the economy of communities } \\
\text { 2. Technical assistance for communities to rehabilitate and } \\
\text { reconstruct housing } \\
\text { 3. To facilitate the communities to rehabilitate their economy }\end{array}$ \\
\hline Social Sectors & $\begin{array}{l}\text { To rebuild infrastructures such as schools, health and religion } \\
\text { facitilties, }\end{array}$ \\
\hline Cross-Sectoral & $\begin{array}{l}\text { 1. To recover environment ecosystem in the disaster zone } \\
\text { 2. To rebuild the government facilities }\end{array}$ \\
\hline
\end{tabular}

Source: Action Plan for Post-Merapi Eruption Recovery, Bappenas, 2010

Through Table 2 it can be seen that the identification of recovery needs per sector will be very important and instrumental, as a reference in the preparation of action plans in much more detail from the supply side, to be able to answer the needs of recovery from the demand side. 
Figure 6. Priority Activities for the Post-Disaster Recovery Action Plan

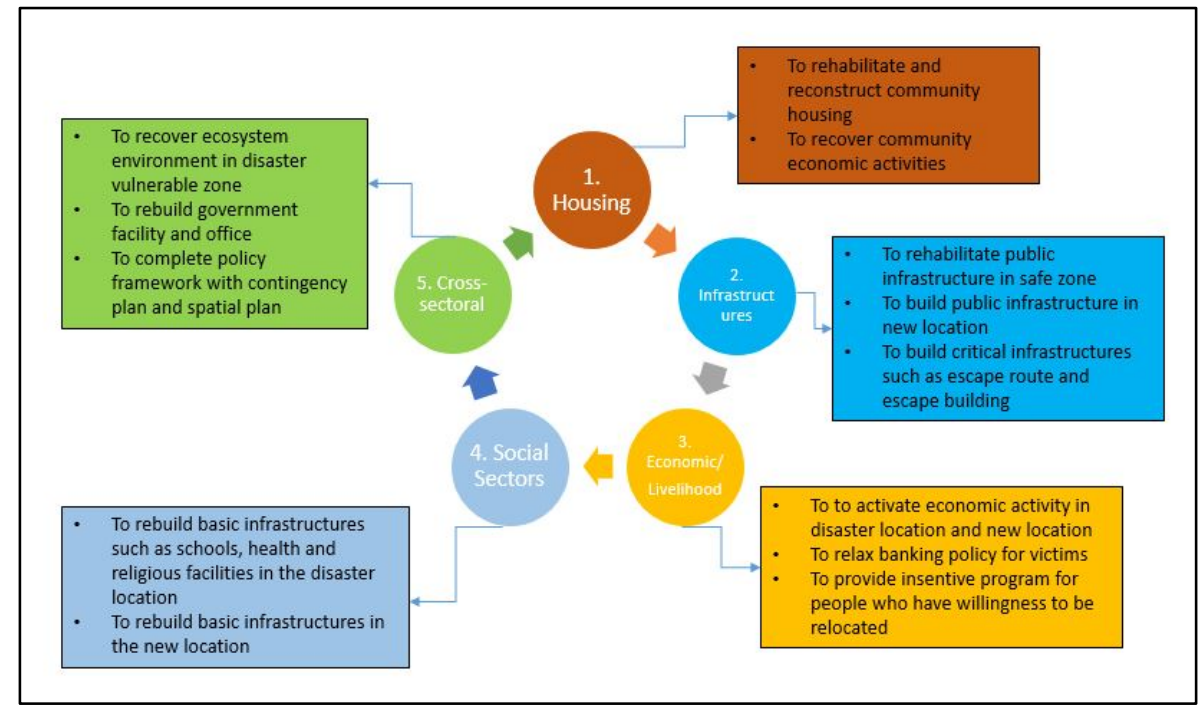

Source: Framework for Post-Disaster Recovery Action Plan, Bappenas, 2017

Furthermore, through Figure 6, it can be further seen that for each field of recovery, there are several priority programs and activities that specifically provide an indication of needs and several factors that need to be considered, including considering the dimensions of capacity in managing post-disaster recovery in the immediate-term, continued in short, medium to long-term frameworks.

Table 3. Framework for Financing the Post-Disaster Recovery Process

\begin{tabular}{|c|c|c|c|c|}
\hline & $\begin{array}{l}\text { National } \\
\text { Government }\end{array}$ & $\begin{array}{l}\text { Provincial } \\
\text { Government }\end{array}$ & $\begin{array}{l}\text { District/Municipal } \\
\text { Government }\end{array}$ & $\begin{array}{l}\text { Private Sectors, Community, } \\
\text { Donors, Disaster Recovery } \\
\text { Funds }\end{array}$ \\
\hline Emergency Relief & $\begin{array}{l}\text { Ready fund/Central } \\
\text { Government Budget } \\
\text { (APBN) }\end{array}$ & $\begin{array}{l}\text { Ready fund/Local } \\
\text { Budget (APBD) }\end{array}$ & $\begin{array}{l}\text { Basic service for } \\
\text { vulnerable } \\
\text { group/local budget } \\
\text { (APBD }\end{array}$ & $\begin{array}{l}\text { Complement with } \\
\text { government programs }\end{array}$ \\
\hline $\begin{array}{l}\text { Housing and } \\
\text { Settelement } \\
\text { Infrastructures }\end{array}$ & $\begin{array}{l}\text { Social Assistance } \\
\text { Grants/Program in } \\
\text { the ministries }\end{array}$ & & & $\begin{array}{l}\text { Complement with } \\
\text { government programs }\end{array}$ \\
\hline Infrastructures & APBN & Provincial Budget & Municipal Budget & $\begin{array}{l}\text { Complement with } \\
\text { government programs }\end{array}$ \\
\hline Social Sectors & APBN & Provincial Budget & Municipal Budget & $\begin{array}{l}\text { Complement with } \\
\text { government programs }\end{array}$ \\
\hline Economic & APBN & Provincial Budget & Municipal Budget & $\begin{array}{l}\text { Complement with } \\
\text { government programs }\end{array}$ \\
\hline Cross-Sectoral & APBN & Provincial Budget & Municipal Budget & $\begin{array}{l}\text { Complement with } \\
\text { government programs }\end{array}$ \\
\hline
\end{tabular}

Source: Framework for Post-Disaster Recovery Action Plan, Bappenas, 2010 
In the preparation of an operational Action Plan, support from an adequate post-disaster recovery funding framework is needed and is sourced from a variety of possible funding sources. Therefore, in the formulation of the rehabilitation and reconstruction action plan and post-disaster recovery, a funding framework can be mobilized and consolidated to support the recovery process at each stage and for each field of recovery, sourced not only from Central Government funding sources, but also funding sources from the Provincial and District/City Local Governments, including from non-government funding sources, especially from the business community and the wider community. In Table 3 it can be observed, the funding source framework of the post-disaster recovery action plan according to the recovery sector, as a reference in the formulation of action plans and monitoring and evaluation of their implementation in a sustainable manner.

\section{Housing and Settlement Recovery Strategy}

Since housing and settlements are usually the most affected sectors of natural disasters, especially geological disasters such as earthquakes and hydrometeorological disasters such as floods and landslides, the recovery strategy needs to pay attention to several issues and problems that are often faced starting from the damage and loss assessment process. post-disaster needs assessment, until the preparation of an action plan and monitoring and evaluation of its implementation.

In relation to settlement management policies, several important things need to be considered including: First, the managing of resettlement of disaster victims in 3 (three) stages, which consists of: construction of temporary housing where residents are accommodated in temporary tents until construction of shelters is completed, construction of permanent housing in-situ around the shelters, as well as relocation of all disaster-prone settlements to new locations ex-situ; Secondly, the victims of the disaster occupy an emergency tent for a maximum of 2 months until the building of shelters is completed; Third, temporary shelter is occupied for 6 months to 1 year until the construction of permanent housing is completed; and Fourth, permanent housing will be built around the location of shelters or at the relocation new location.

Meanwhile, by considering the existence of 2 (two) alternatives for postdisaster housing and settlement recovery, then in particular for in-situ housing recovery, then the establishment of temporary housing is still based on community aspirations by following the criteria of location close to the location of previous settlements, are joined by residents of the same village, and are permitted to continue to use the name of the previous village and continue to function the previous village apparatus. Whereas if the choice is through ex-situ recovery, by relocating settlements and building new houses at the designated relocation sites, completeness of basic housing and settlement facilities is needed, including to pay attention to the process of restoring housing and 
settlements based on local communities through community based housing and settlement rehabilitation and reconstruction.

As shown in Figure 7 below, it can be seen that the process of recovery of housing and settlements at least follows 3 (three) main stages, starting from the determination of relocation locations, direct involvement of the community in the recovery process with the help of technical facilitators, and the assistance scheme combined with the economic recovery process of the community and region through the development of new economic activities sustainably.

Addressing to Figure 7, it is necessary to consider that the process of restoring housing and settlements ex-situ becomes increasingly complex, with several issues of relocation of housing and settlements that include the provision of land, revision of spatial planning, provision of facilities and infrastructure to new locations, and allocation of possible funding sources; while the challenges at the initial location include: First, data collection on land/building owners who are willing to take part in relocation; Second, the implementation of procedures for revoking urgent rights, including due to natural disasters, by the President, in accordance with Law No. 20 of 1961; Third, estimates and approaches to compensation for land, buildings, plants, other objects related to land; and challenges to new locations, including: a) Land acquisition according to disaster risk reduction criteria; b) funding for preparation of clear and clean area and environment to develop; and c) funding mechanism and implementation of construction of disaster victims housing in new locations.

Figure 7. Housing and Settlement Recovery Framework ex-situ (relocation)

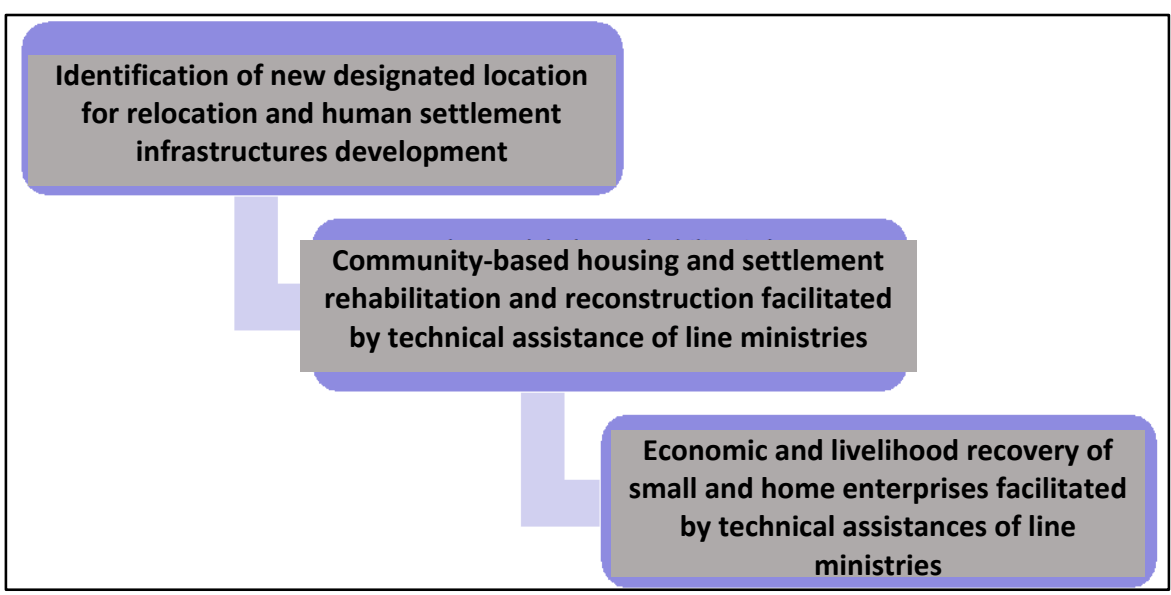

Source: Framework for Recovery of Post-Disaster Housing and Settlements, Bappenas, 2011

\section{Post-Disaster Economic Recovery Strategy}

After understanding the process of recovery of housing and settlements which is the most complex but urgent in the post-disaster recovery phase, on the other hand the economic recovery process of the community and the region 
requires recovery stages that require relatively longer time in the medium and long-term.

Figure 8. Stages of the Post-Disaster Economic Recovery Process

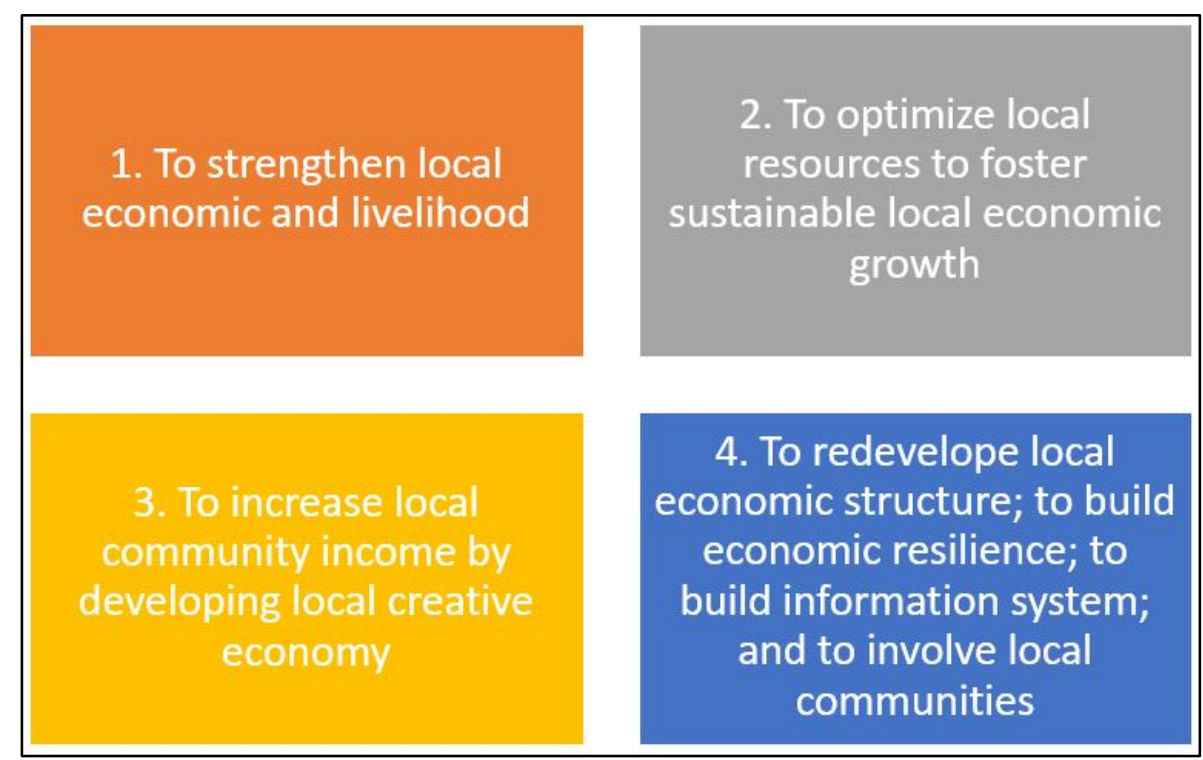

Source: Post-Disaster Economic Recovery Framework, Bappenas, 2011

Through Figure 8 , it can be observed that the economic recovery process of the affected communities and regions can be identified as 4 (four) stages and considerations as follows: First, directed towards recovery and then increasing local economic activities; Second, local economic activities are developed based on local potential resources; Third, the rebuilding of the local economy is focused on the creative economy and is based on local wisdom to ensure its sustainability; and Fourth, focused on leading economic sectors that can become the prime movers of the economy of the people and regions, supported by data and information as well as maps of disaster risk that need to be considered in the efforts to develop a sustainable local and regional economy.

Learning from the experiences of previous post-disaster economic recovery from several other disasters that have been carried out, particularly in the aftermath of the Yogyakarta earthquake and Mount Merapi eruption, can be summarized in Figure 9, that the processes and stages of local economic recovery and regions require a relatively longer time compared to restoration of other fields, thus requiring a recovery strategy in the short and mediumterms, which in its implementation requires data collection and mapping of the needs of a more complete and accurate spatial based post-disaster economic recovery, so that recovery targets that are not only to recover to the initial condition can be achieved, but more directed towards achieving its 
development goals and the increasing economic conditions of local communities and regions that are better, safer and more sustainable in the longterm.

Figure 9. Framework for Post-Disaster Economic Recovery Stages

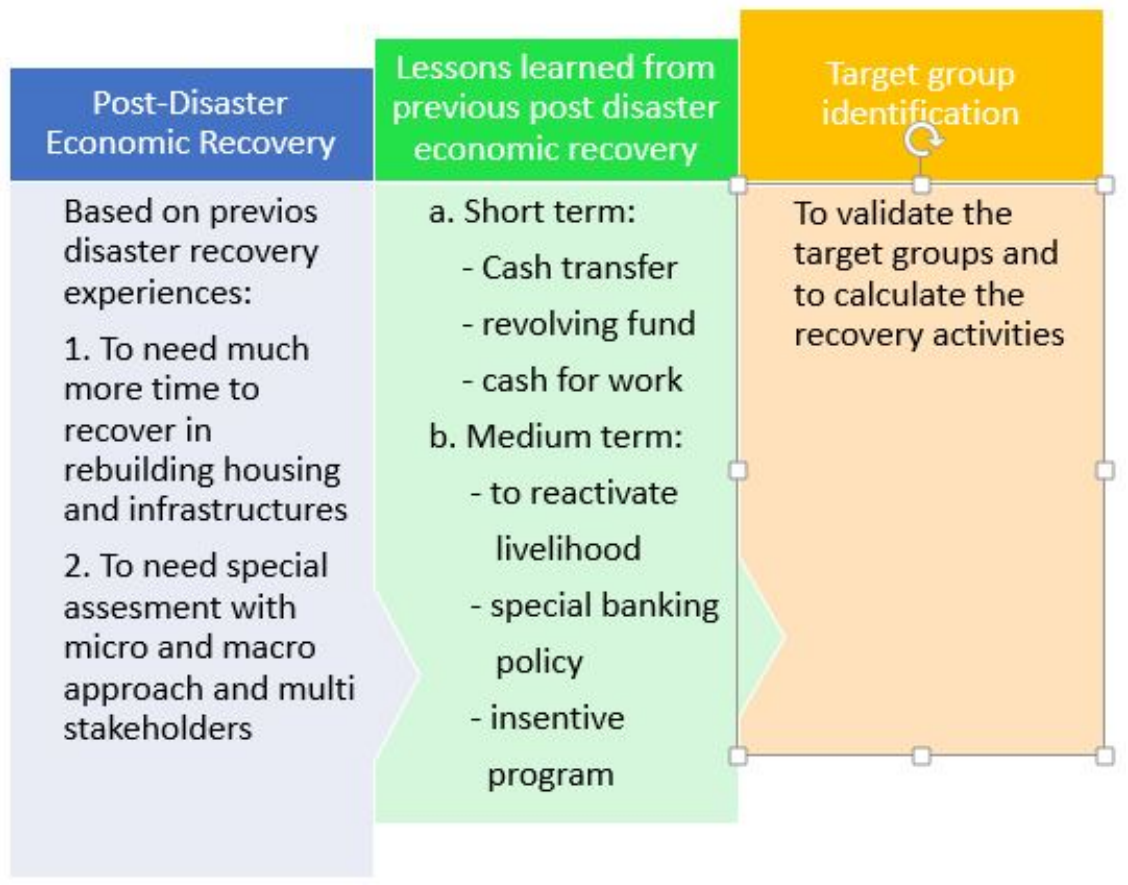

Source: Post-Disaster Economic Recovery Framework, Bappenas, 2012

\section{Conclusion and Implication to Lombok Post-Disaster Recovery}

Learning from the experience of post-disaster recovery above, what are the implications for handling earthquake disasters in Lombok July-August 2018 ? Taking into account that the stages of emergency response stages have ended on 25 August 2018, then during the transition to the early recovery stage and the stages of rehabilitation and reconstruction and recovery in the short-term, short-to-medium term, the following strategic issues need to be considered.

First, in anticipation of the possibility of further continuation of the earthquake or a new earthquake, the transition stage besides remaining focused on completing the damage and loss assessment process (JITUPASNA) including post-disaster needs assessment (PDNA) also still cannot be completely completed, but the preparation of plans the final rehabilitation and reconstruction and recovery and post-disaster action must still be formulated in a final framework, taking into account the directions contained in the Presidential Instruction Number 5 year 2018 concerning the Acceleration of Post-Earthquake Recovery and Rehabilitation and Reconstruction in the West 
Nusa Tenggara Province, including some recovery activities that have been scheduled for urge until the end of 2018, which will be supported by a financing allocation plan through the National Budget of 2018 source for the initial recovery process that is urgent, especially for the handling of refugees in temporary shelter, repair and rebuilding of housing and settlements and urgent repair of functions of public facilities, both through ready-to-use funds for emergency relief and early recovery in the transition phase after the end of the emergency response phase.

Second, noting that the status of the earthquake disaster in Lombok July-August 2018 was not designated as a national disaster and still provincial disaster status, within the provincial scope and the scale is still not too large, the role and responsibilities of the Governor of NTB need to be continued through fostering and supervision support and financing allocated by the Central Government. The challenges faced are the readiness of the Regional Government of NTB Province and the seven District/City Governments in the affected areas to be responsible for disaster management in their respective regions, even though the Central Government continues to provide support and assistance to respective local governments whose areas are affected by disasters, especially through assignments in the Presidential Instruction No. 5 year 2018, in particular the financing is still borne entirely from the National Government Budget (APBN) source, by not closing the possibility of allocating funds sourced from the Provincial and Local Government Budgets (APBD), while still taking into account regional fiscal capabilities that are still not ready, but are expected to be gradually increased through contingency funds from the Provincial and Local Budgets starting in 2019, which is in line with Law Number 23 of 2014 on Regional Governance and Government Regulation Number 2 of 2018 concerning Minimum Service Standards which have delegated authority to disaster management explicitly to local governments in framework for fulfilling minimum service standards at the local level, including for reminding public order in disaster management. Furthermore, according to the priority of the use of village funds that have been established through the Regulation of the Ministry of Village, that village funds can also be used as a complementary source of funding for post-disaster management in villages affected by the earthquake disaster in Lombok July-August 2018.

Third, the role and responsibilities of the Governor of NTB which, according to the mandate of Presidential Instruction Number 5 Year 2018, are responsible for handling post-earthquake disaster in Lombok 2018, so that leadership is expected to be able to coordinate at the field level to the directly affected by the Lombok earthquake. Learning from the experience of managing post-earthquake disasters in Yogyakarta in 2006 and Mount Merapi eruption in 2010, the role and responsibilities of Sultan Hamengku Buwono $X$ as the Governor of DIY are very significant and can be successfully used to directly 
coordinate the recovery process of the 2006 Yogya earthquake and eruption of Mount Merapi in 2010, where all Regents and Mayors whose areas were directly affected could be coordinated and directly under the control of the Governor of DIY in the complete rehabilitation and reconstruction process of all fields of recovery, while at the same time paying attention to the involvement of the community and non-government partners in the recovery process and stages in immediate, short and medium- term. Moreover, learning from experiences in Yogya and West Sumatra, the Central Government established a Cross-sectoral Agency though National Technical Assistance Team and involved disaster experts, to assist the role and responsibilities of the Governors of Yogya and Governor of West Sumatra, namely through the National Technical Team (TTN) for the post-earthquake Yogyakarta in 2006-2009, and the National Assistance Team (TAN) for the post-West Sumatra earthquake in 2009-2012. Therefore, taking into account that the capacity of the former Governor of West Nusa Tenggara, known as Tuan Guru Bajang who is the leader of Nahdatul Wathon (NW), the biggest Islamic-based organizations for most communities in Lombok and Sumbawa, the leadership of the former Governor of NTB can be optimized in providing direction to the respective government and non-government agencies in the affected regions, including for groups of people affected by disasters, to be able to work together and coordinate in the implementation of the initial recovery process and stages until their continued recovery in an integrated and sustainable manner, carried out through local religious and customary approaches, especially the Sasak tribe that dominates the community in Lombok, while in the Sumbawa region the leadership of the current Governor of NTB who is originally from Sumbawa can be effectively managing the process of recovery in affected districts in Sumbawa Islands. Thus, the role of the Central Government in this matter is to provide facilitation, guidance and supervision to the Governor of NTB in carrying out their duties and responsibilities, in accordance with what is mandated by each respective line ministry in accordance with their respective authorities and responsibilities.

Fourth, in ensuring the long-term and sustainable post-disaster recovery process, the religious and customary approaches that need to be played by the Governor of NTB need to be consolidated and mobilized at the same time to be able to increase the capacity and responsibility of the affected District/City Governments, through the involvement of local communities proactively and sustainably. It is like learning shown from post-earthquake handling in Yogya and Mount Merapi, where the Regional Government in the Province of Yogya has relatively more capabilities and has been tested in conducting post-disaster recovery management, and almost all of them have included disaster risk in their Medium-term Development Plans' (RPJMD) vision and mission, including revising the regional spatial plans (RTRW) based on disaster risk. In the case of Lombok, it is necessary to review the readiness and capacity and commitment of the Provincial and affected Local Governments 
towards disaster management, especially since Lombok has not been directly confronted with disasters, although it still depends heavily on leadership and political will from different head of the regions. Hence, it is expected that support from respective institutions can become partners of the Provincial and affected Local Governments in NTB, such as those that can be played by the various Disaster Risk Reduction Forums (DRR) to collaborate with Provincial and Local Disaster Management Agencies (BPBD) in each region, especially those who are still relatively low in their capacity in the implementation of disaster management.

Fifth, by paying attention to the delegation of authority to carry out disaster management to local governments, including efforts to achieve minimum service standards in the field of public order, especially for postdisaster management and disaster risk reduction, several classical issues in disaster management in this area need to be focused on strengthening and the sharpening of the actual regulatory framework is quite complete, but is still faced with the understanding and concern of the BPBDs which are still relatively very lacking, which is still very dependent on assistance and subsidies from the National Government, but with the issuance of Law Number 23 Year 2014 and Government Regulation Number 2 of 2018 on Minimum Service Standard, the authority of disaster management have become regional and local affairs, so it is time for regions to be able to be independent to be able to be more selfsustained in the implementation of disaster management in their respective regions, and in with the Central Government through relevant ministries, as well as other stakeholders, which can better and sustainably improve the capacity of local governments.

Sixth, the urgent initial recovery process and stages in the late of 2018 until early of 2019, especially those related to the recovery of housing and settlements, as the most significant area affected by the earthquake in Lombok July-August 2018, the process that needs to be carried out as a complement to the process identification of damage and loss assessment and recovery needs, is through assessment of disaster risk in the affected area, which is implemented in revisions to the respective spatial plans (RTRW), which can recommend strategies for the recovery of housing and settlements in an integrated manner at the location directly affected, or possible ex-situ through relocation to new housing and settlement locations, in accordance with spatial regulation recommendations and zoning for safe use for housing and settlements to be built at the agreed location of relocation.

Seventh, then related to the process of recovery in the economic field of the community and the regions, which needs to be carefully planned based on the assessment of economic recovery needs at the community and regional levels for local economic and business activities and investments on a broader scale. Learning from previous strategies that have been applied to other 
disasters, can be used for post-earthquake recovery management in Lombok, especially in a number of leading economic and business activities in the affected areas in Lombok, such as tourism and micro and small-scale businesses as a support for the tourism sector, besides also other productive economic activities in Lombok which became one of the national rice barns. It is also hoped that the action plan for the recovery of the local and regional economies prepared can actually provide a strategic step that can rebuild and restore economic activity, business and investment in Lombok that has the potential to accelerate the rise of the economy in Lombok in the not too distant future, which need to be linked to the role of the Mandalika Special Economic Zone (KEK) in Lombok, which not only became the prime mover of the regional economic development of NTB Province but also became a regional center for economic growth at the national level. 